\title{
TOTAL BACTERIAL COUNTS OF RAW MILK IN EASTERN TERAI OF NEPAL
}

\author{
Lekh Raj Dahal MSc${ }^{1}$, Dainik B. Nepali Karki $\mathrm{PhD}^{2}$ and Ramashish Shah $\mathrm{MSc}^{3}$
}

\begin{abstract}
This study was carried out to evaluate the quality of raw milk measured by Total Bacterial Count (TBC). Bulk raw milk for bacteriological study was carried out in Regional Veterinary Laboratory (RVL), Biratnagar. Altogether, 520 milk samples for TBC were examined at farm and plant levels. Results showed a great variability of TBC for the overall study period. The lowest TBC $(2.78 \times 106)$ and the highest TBC $(13.299 \times 106)$ at two milk collection units revealed nearly fivefold difference. The results of mean TBC at farm $(9.03 \times 105)$ was nine fold of international standard (1 x 105), and mean TBC at plant (104.71 x 105) reached 104 folds the international standard. The TBC at farm level were non significant $(P>0.05)$ for overall experimental period where as most of TBC at plant level differed $(p<0.01)$ significantly. TBC at farm level differed significantly $(P<0.01)$ from each record of same date at plant level. The highest number of TBC $(16.5 \times 106)$ was observed in the month of September, which was significantly $(P<0.01)$ different from the rest of the months. The results obtained from the study indicated that the current situation is critical and needs real improvement from production point to processing plant.
\end{abstract}

Key words: Raw milk, Total Bacterial Count (TBC)

\section{INTRODUCTION}

Milk is synthesized in specialized cells of the mammary gland and is virtually sterile when secreted into the alveoli of the udder (Tolle, 1980). Beyond this stage of milk production, microbial contamination can generally occur from three main sources (Bramley and McKinnon, 1990); from within the udder, from the exterior of the udder and from the surface of milk handling and storage equipment. All these sources of contamination influence the Total Bacteria Count (TBC) or Standard Plate Count (SPC). Cattle and buffaloes provide direct cash income and are living bank for marginal farmers (Nakao, 2005). To target the export market the quality of the milk is to be standardized and pricing should be based on milk quality. Products should be diversified so that they suit the export market. However, hygienic and quality regulations for production and distribution of milk are more relaxed in Nepal, and are not subject to specific microbiological standards in a legal sense. Gaps and deficiencies in such standards are to be identified and made compatible with codex, a standard setting organization of World Trade Organization (WTO) and South Asia Free Trade Agreement (SAFTA) which have potentially opened markets in the South Asia Region. Nepal will have to compete aggressively on price along with quality. Dairy farming is one of potential agri-business in the eastern Terai. Thirteen percent of total milk production of the country is shared by Eastern Terai, out of which Sunsari and Morang districts occupy about 38.28 \% of milk production of Eastern Terai (MOAC, 2007). Hence, the present study was designed to evaluate the quality of raw milk as influenced due to level of management and milk handling procedures on TBC as the bulk milk quality indicator at production point and processing plant and to examine the trend of different milk quality variables for the study period.

\section{MATERIALS AND METHODS}

The site selected for this study was Kamadhenu Dairy Development and Cooperative Ltd (KDDC), Tarahara Sunsari and its command area (milk-shed area of Morang and Sunsari

\footnotetext{
${ }^{1}$ Senior Veterinary Officer, Ph. 025530667 and 9842031653 (M), Email: Irdahal2003@yahoo.com

${ }^{2}$ Professor, IAAS, Rampur, ph. 9855056176

${ }^{3}$ Lecturer, IAAS, Rampur, Ph. 9845051032 (M), Email: ramashish_shah@yahoo.com
} 
districts). The KDDC was chosen as study site because it represents one of the successful dairy cooperatives run by livestock farmers themselves in Nepal. Furthermore Sunsari and Morang are leading milk producing districts after Ilam in organized milk market of Eastern Nepal (MOAC, 2007). The KDDC, Tarahara is situated around 4 municipalities: Dharan, Itahari, Inaruwa and Biratnagar, heart of eastern Terai of Nepal, which distributes and markets about 6000 liters of milk daily with storage capacity 20,000 liters.

Raw milk samples ( $25 \mathrm{ml}$ each) were collected aseptically into sterile screwed test tube in the morning at two points - one from bulk milk of each milk collection unit just before pouring into milk plant (hereafter referred as milk at plant level or MPL) and another randomly selected three farmhouses of each milk collection unit (hereafter referred as milk at farm level or MFL). The collected samples were kept in an ice box, and then processed immediately after delivery to the Regional Veterinary Laboratory (RVL), Biratnagar. Ten samples, one from each milk collection unit at plant level and 30 samples from randomly selected three farmhouse of each milk collection unit at farm level were collected. Altogether a total of 520 raw milk samples were collected at fortnightly interval from ten

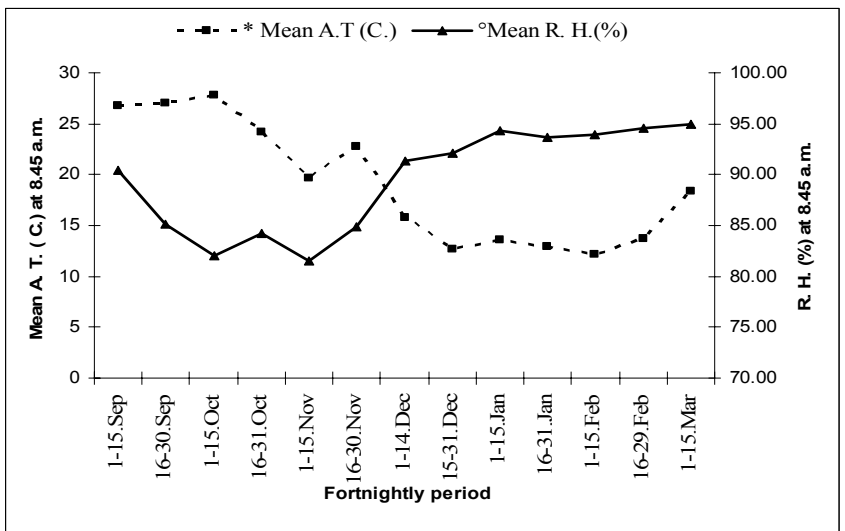
milk collection units of KDDC, Tarahara during mid September 2007 to mid March 2008.

Every milk collecting unit was considered as a block to minimize the variation. Two Factor Randomized Complete Block Design (RCBD) was applied as factor A (dates), and factor B (MPL and MFL). Microorganism counts were expressed in colony forming units (cfu) per $\mathrm{ml}$ of milk.

Fig. 1: Trend of fortnightly average dry bulb temperature and relative humidity recorded at 8.45 a.m. at Tarahara, Sunsari over six months study period ( *A. T. : Ambient Temperature; R. H. : Relative Humidity .

The milk samples were subjected to TBC in the testing laboratory. TBC was accomplished as per Quinn et al. (1994) who prescribed serial ten-fold dilutions of the milk sample. Hence, TBC were determined by the pour plate method on nutrient agar. Fortnightly meteorological data related to dry bulb temperature and relative humidity is presented in Fig.1 which was obtained from Koshi Basin Office, Dharan, Sunsari in 2008. TBC data obtained from experiments were transformed into decimal logarithm scale to normalize their frequency distributions. Descriptive analysis was performed using MS Excel 2003. Analysis of variance (ANOVA) was performed according to Gomez and Gomez (1984). Means were separated by DMRT using MSTAT-C version 1.3 computer package.

\section{RESULTS AND DISCUSSION}

\section{TBC AT DIFFERENT MILK POCKET AREA}

Mean TBC per $\mathrm{ml}$ of milk of different MCU of KDDC, Tarahara is presented in Table 1. Accordingly, maximum (13.299 x 106) TBC per ml of milk, which was recorded in Bahuni area indicating the most miserable condition of milk handling and management differed significantly $(\mathrm{P}<0.01)$ from other milk pocket areas. Minimum $(2.78 \times 106)$ TBC per $\mathrm{ml}$ of milk which was recorded in Santinagar, Itahari area showing the better condition of milk production was significantly different $(P<0.01)$ from that of Bahuni, Lalpur and Letang area 
but did not differ significantly $(P>0.05)$ from rest of $M C U$. The high variability of TBC from MCU to MCU in the present study was supported by the finding of Srairi et al. (2006).

Heavy contamination was found in milk collected from Bahuni, Lalpur and Letang areas. It might be due to the result of long distance of these MCU to reach to milk plant, which took almost more than 5 hours in transportation. Especially, milk from these three MCU was delivered to plant around 10:00 to 10:30 am and until then there was a rise in an ambient temperature which automatically influenced in milk temperature as well. The increased temperature might have favored bacterial multiplication of milk. Similar observation was made earlier by CUCES (1999) who observed very low increment of bacterial population at $400 \mathrm{~F}$ and 5 fold at $500 \mathrm{~F}, 15$ fold at $600 \mathrm{~F}, 700$ fold at $700 \mathrm{~F}$ and 3000 fold at $800 \mathrm{~F}$ indicating a high positive relationship between temperature rise and multiplication of bacteria.

Table 1: Mean TBC of raw milk of different MCU of KDDC, Tarahara Nepal

\begin{tabular}{lll}
\hline MCU & Transformed TBC means & Original TBC means \\
\hline Upper Santinagar, Itahari-3 & $6.348 \mathrm{bcd}$ & $3.587 \times 10^{6} \mathrm{bcd}$ \\
Latijhoda, Sundarpur & $6.310 \mathrm{~d}$ & $4.310 \times 10^{6} \mathrm{~d}$ \\
Banuni & $6.529 \mathrm{a}$ & $13.299 \times 10^{6} \mathrm{a}$ \\
West Baklauri & $6.277 \mathrm{~d}$ & $4.894 \times 10^{6} \mathrm{~cd}$ \\
Bamhrapur, Hanspokha & $6.306 \mathrm{~d}$ & $3.582 \times 10^{6} \mathrm{~d}$ \\
Santinagar, Itahari & $6.310 \mathrm{~d}$ & $2.780 \times 10^{6} \mathrm{~d}$ \\
Mrigauliya, Gothgaon, Salakpur And & $6.338 \mathrm{bcd}$ & $5.030 \times 10^{6} \mathrm{bcd}$ \\
Biratchowk & $6.314 \mathrm{~cd}$ & $3.516 \times 10^{6} \mathrm{~cd}$ \\
Kumarkhat, Baklauri & $6.420 \mathrm{~b}$ & $6.880 \times 10^{6} \mathrm{~b}$ \\
Lalpur, Singiya & $6.403 \mathrm{bc}$ & $8.990 \times 10^{6} \mathrm{bc}$ \\
Letang & 2.41 & \\
CV\% &
\end{tabular}

Means in column followed by different letters are significantly different ( $\mathrm{P}=0.01)$ by Duncan's Multiple Range Test (DMRT).

\section{TBC AT PLANT AND FARM LEVELS}

The mean TBC at MPL and MFL for the study period (September15, 2007 to March 15, 2008) are presented in Table 2.

Table 2: Mean TBC of raw milk at plant level (MPL) and milk at field level (MFL) at KDDC, Tarahara Nepal

\begin{tabular}{lcccc}
\hline \multirow{2}{*}{ Date of sample collection } & \multicolumn{2}{c}{ Transformed TBC means } & \multicolumn{2}{c}{ Original TBC means } \\
\cline { 2 - 5 } & MFL & MPL & MFL & MPL \\
\hline September 15, 2007 & $6.020 \mathrm{~h}$ & $7.406 \mathrm{a}$ & $1.066 \times 10^{6} \mathrm{~h}$ & $32.930 \times 10^{6} \mathrm{a}$ \\
September 30, 2007 & $5.996 \mathrm{~h}$ & $7.351 \mathrm{a}$ & $1.013 \times 10^{6} \mathrm{~h}$ & $31.002 \times 10^{6} \mathrm{a}$ \\
October 15, 2007 & $5.988 \mathrm{~h}$ & $7.162 \mathrm{~b}$ & $0.988 \times 10^{6} \mathrm{~h}$ & $16.962 \times 10^{6} \mathrm{~b}$ \\
October 31, 2007 & $5.978 \mathrm{~h}$ & $7.072 \mathrm{bc}$ & $0.961 \times 10^{6} \mathrm{~h}$ & $14.020 \times 10^{6} \mathrm{bc}$ \\
November 15, 2007 & $5.951 \mathrm{~h}$ & $6.964 \mathrm{~cd}$ & $0.902 \times 10^{6} \mathrm{~h}$ & $10.610 \times 10^{6} \mathrm{~cd}$ \\
November 30, 2007 & $5.939 \mathrm{~h}$ & $6.862 \mathrm{de}$ & $0.875 \times 10^{6} \mathrm{~h}$ & $8.205 \times 10^{6} \mathrm{de}$ \\
December 14, 2007 & $5.934 \mathrm{~h}$ & $6.738 \mathrm{e}$ & $0.867 \times 10^{6} \mathrm{~h}$ & $6.105 \times 10^{6} \mathrm{e}$ \\
December 31, 2007 & $5.914 \mathrm{~h}$ & $6.604 \mathrm{f}$ & $0.831 \times 10^{6} \mathrm{~h}$ & $4.302 \times 10^{6} \mathrm{f}$ \\
January 15, 2008 & $5.895 \mathrm{~h}$ & $6.358 \mathrm{~g}$ & $0.795 \times 10^{6} \mathrm{~h}$ & $2.495 \times 10^{6} \mathrm{~g}$ \\
January 31, 2008 & $5.885 \mathrm{~h}$ & $6.281 \mathrm{~g}$ & $0.784 \times 10^{6} \mathrm{~h}$ & $2.000 \times 10^{6} \mathrm{~g}$ \\
February 15, 2008 & $5.931 \mathrm{~h}$ & $6.313 \mathrm{~g}$ & $0.863 \times 10^{6} \mathrm{~h}$ & $2.116 \times 10^{6} \mathrm{~g}$ \\
February 29, 2008 & $5.942 \mathrm{~h}$ & $6.393 \mathrm{~g}$ & $0.888 \times 10^{6} \mathrm{~h}$ & $2.612 \times 10^{6} \mathrm{~g}$ \\
March 15, 2008 & $5.949 \mathrm{~h}$ & $6.424 \mathrm{~g}$ & $0.901 \times 10^{6} \mathrm{~h}$ & $2.762 \times 10^{6} \mathrm{~g}$ \\
\hline
\end{tabular}

Means in row and column followed by different letter are significantly different ( $\mathrm{P}=0.01)$ by DMRT.

\section{COMPARISON OF TBC WITH INTERNATIONAL STANDARD}

The results of mean TBC at MFL $(9.03 \times 105)$ was nine times greater than that of international standard (EU standard) $(1 \times 105)$ whereas mean TBC at MPL $(104.71 \times 105)$ reached 104 fold the international standard due to conducive ambient temperature and 
relative humidity for the growth of bacteria (Fig.1) accompanied by lacking of milk refrigeration in the situation of long distance milk transportation. Srairi et al. (2006) also reported similar problems concerning hygienic quality of raw milk received by MCU in Morocco. Similarly, Aumaitre (1999) observed similar results due to lapses in milk sanitation. Litwińczuk et al. (1999) and Przysucha et al. (2003) documented difficulties to obtain high quality milk during the summer season. All of them reported that higher air temperatures favour the increase of bacteria number, especially on the surfaces of no good enough cleaned up milking equipment which were the potential source of infection. To date, TBC is not accounted as standard parameter for enhancement of raw milk quality in Nepal. Although TBC $(1 \times 105)$ is considered as international standard adopted by EU, Brazilian National Program of Milk Quality adopted 1.0 × $106 \mathrm{cfu} / \mathrm{ml}$ of mesophilic aerobic count as national standard, however, ISI has laid down SPC standard $(<2 \times 105)$ for very good quality milk in India. It is too late to standardize different milk quality parameters in Nepal to cope with provision of WTO and to provide healthy milk and milk products to consumers.

\section{TREND OF FORTNIGHTLY RECORDINGS OF TBC}

Trend of fortnightly recordings of overall mean TBC of MFL and MPL, and mean TBC at MFL and MPL per ml milk have been depicted in Fig.2. Overall mean TBC and mean TBC at MPL were considerably higher during September and October than the rest of months. Lower microclimatic temperature during winter also reduced bacterial count $(<10 \times 106)$. However, mean TBC at MFL was considerably very low $(\leq 1.00 \times 106)$ which remained almost unchanged over study period. The present observation of reduced number of TBC, as winter

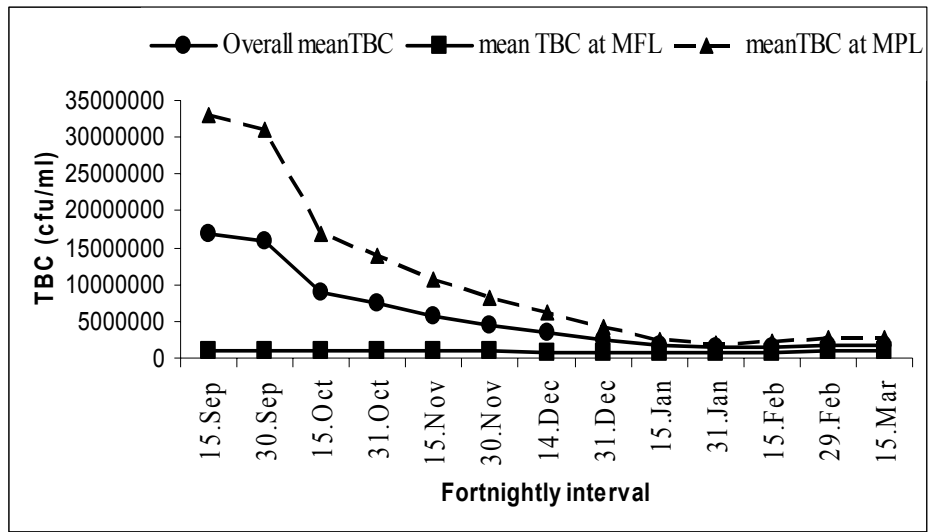
advanced, was in agreement with earlier finding of Srairi et al. (2008) who also observed the highest Log TBC of raw milk during the hottest months of July followed by August to November and the lowest Log TBC during the coolest or driest month of December, January.

Fig. 2: Fortnightly recordings of mean TBC of MFL and MPL and mean TBC at MFL and MPL per ml milk at KDDC, Tarahara Nepal (15 Sept. 2007 to 15 Mar. 2008)

A higher number of TBC was observed in the month of September as compared to October which might be due to high mean ambient temperature recorded for the same month (Fig.1). The trend of bacterial load showed a positive relation with prevailing ambient temperature. Data obtained from pervious study also indicated higher microbial counts during summer (Tirard-Collet et al., 1991). A similar observation was recorded by Zweifel et al. (2006) in different agro-climatic region in goat milk.

\section{CONCLUSION}

The results obtained during this work on the hygienic quality of raw milk in Nepal indicated that the current situation is critical and needs real improvement. In effect, a great majority 
of milk samples had very high level of bacteria. Lacking refrigeration facilities of milk during transportation from production to processing sites contributed higher microbial load of raw milk. Microbial counts as quality indicator of raw milk and the possible impact of specific influence factors are of central importance, and such specific influencing factors are therefore of great concern in hygienic milk production. The following suggestions are made in order to avail quality milk and milk products to the consumers.

1. Government should include legal enforcement on TBC of marketed milk considering Nepalese situation.

2. NDDB should bring all dairy stakeholders together to set milk pricing policy in order to stimulate the awareness among farmers and processors for quality milk production.

3. Milk refrigeration system during transportation as well as in the milk collection units especially to those areas which are located far from the plant should be developed immediately.

\section{REFERENCES}

Aumaitre, A. 1999. Quality and safety of animal products. Livestock Production Science 59:113-124.

Bramley, A. J. and C. H. McKinnon. 1990. The microbiology of raw milk. In: R. K. Robinson (ed.).Dairy Microbiology, Vol. 1. Elsevier Science Publishers, London. pp. 163-208.

CUCES (The Clemson University Cooperative Extension Service). 1999. Clemson extension dairy science bulletin . South Carolina. USA. 13 p.

Gomez, K. A. and A. A. Gomez. 1984. Statistical procedures for agricultural research ( $7^{\text {th }}$ edition). John Wiley \& Sons Inc. Singapore. pp. 84 - 129.

Litwińczuk A., M. Tomasiak and J. Król. 1999. Changes in classification of commercial milk after introduction of new quality standard. Electronic Journal of Polish Agricultural Universities, 47: 121-127.

MOAC (Ministry of Agriculture and Cooperatives) 2007. Statistical information on Nepalese agriculture 2006-2007. Agribusiness Promotion and Statistics Division. Singh Durbar, Kathmandu, Nepal. pp. 34 -35

Nakao. 2005. Possibilities of increasing milk and calf production in cattle and buffaloes in Chitwan by improvement of reproductive management. In: Seminar presented in IAAS, Rampur, Chitwan, January 9, 2005.

Przysucha T., H. Grodzki, K. Zdziarski and M. Trzaska. 2003. The influence of delivery system, monthly milk supply and season on TBC in raw milk qualified to the highest quality classes. Electronic Journal of Polish Agricultural Universities 68(1):115-122

Quinn, P. J., M. E. Carter, B. K. Markey and G. R. Carter. 1994. Clinical veterinary microbiology. Wolfe Publishing, pp.209-236.

Sraïri, M. T., H. Benhouda, M. Kuper and P. Y. Le Gal. 2008. Effect of cattle management practices on raw milk quality on farms operating in a two-stage dairy chain. Tropical Animal Health Production, 10:1007.

Srairi, M. T., J. Moudnib, L. Rahho and A. Hamama. 2006. How do milking conditions affect the hygienic quality of raw milk? Case study from Moroccan dairy farms. Livestock Research for Rural Development, 18(7): 1-9.

Tirard-Collet, P., J. A. Zee, L. Carmichael and R. Simard. 1991. A study of the microbiological quality of goat milk in Quebec. Journal of Food Products, 54: 263-266.

Tolle, A. 1980. The microflora of the udder. In: Factors influencing the bacteriological quality of raw milk. International Dairy Federation Bulletin, Document 120. 4 p.

Zweifel, C., J. E. Muehlherr, M. Ring, R. Stephan. 2005. Influence of different factors in milk production on standard plate count of raw small ruminant's bulk-tank milk in Switzerland. Small Ruminant Research, 58: 63-70.

\section{ACKNOWLEDGEMENT}

The financial supports from 'Heifer International Nepal, Hattiban Lalitpur, Nepal' and 'National Agricultural Research and Development Fund, Singhdarbar Plaza, Kathmandu' are thankfully acknowledged. 